\title{
A Case Study on Peer Review and Lecturer Evaluations in an Academic Setting
}

\author{
Nor Kamaliana Khamis ${ }^{1}$, Abu Bakar Sulong ${ }^{1}$ \& Baba Md Deros ${ }^{1}$ \\ ${ }^{1}$ Department Mechanical and Materials Engineering, Faculty of Engineering and Built Environment, Universiti \\ Kebangsaan Malaysia, Selangor, Malaysia \\ Correspondence: Nor Kamaliana Khamis, Department Mechanical and Materials Engineering, Faculty of \\ Engineering and Built Environment, Universiti Kebangsaan Malaysia, 43600 UKM Bangi, Selangor, Malaysia. \\ Tel: 60-3-8921-6967. E-mail: kam@eng.ukm.my
}

\author{
Received: October 5, 2012 Accepted: November 23, 2012 Online Published: November 30, 2012 \\ doi:10.5539/ass.v8n16p192 URL: http://dx.doi.org/10.5539/ass.v8n16p192
}

\begin{abstract}
Students can enhance their soft skills and learning experience through the use of group projects. However, evaluating group project performance has become very challenging. This paper presents the concept of group management in measuring individual performance in group projects in an academic setting. Individual performances in similar courses were also compared based on two consecutive semesters (Semesters 1 and 2). The respondents for this study were first year students who attended similar courses for both semesters. Performance measurement was based on peer review and lecturer evaluations. The criteria for these evaluations were similar for both semesters. The current study aims to determine the weaknesses and strengths of an individual in a group, and relate them with group performance based on the individual presentation marks. The study also analyzes the relationship between these two performance tools. Findings indicate that peer review and lecturer evaluations can be used to determine the performance of students in a group project, and that these two evaluation tools are not significantly correlated.
\end{abstract}

Keywords: group project, peer review, lecturer evaluation, individual performance, correlation

\section{Introduction}

Previous research suggests that involvement in extracurricular activities and group projects is a good exercise to prepare students for the real world (Ballantine \& Larres, 2007; Mahenthiran \& Rouse, 2000; Clary, 1997). According to past surveys, most employers are interested in employees who have personal values, a good working attitude, intellectual and communication skills, and knowledge that leads to success (Muhamad et al., 2008; Warn \& Tranter, 2001; Coopers \& Lybrand, 1998; Cappelli, 1992). These skills can be developed through activities that emphasize teamwork, which can be conducted during study periods. Strategy and well-defined tasks are necessary to drive effective teamwork, an important criterion in the success of projects (Hoegl \& Gemuenden 2001). Pfeffer (1983) believes that teamwork affects the decision-making process, which, in turn, influences outcomes (Liao \& Tsai, 2001; Ingram, 1996; Keck \& Tushman, 1993; Jackson, 1992).

In recent years, group projects have become an important element of higher education. However, managing group projects is quite problematic due to the different personalities of team members (GSN, 2012; Buchanan, 1998). Integrating teamwork in the classroom is also often challenging due to the uneven efforts, contributions, and involvement of individual team members (Friedman et. al, 2008; Gueldenzoph \& May, 2002). For example, a number of students are reluctant to convey their ideas in a group meeting, whereas other students tend to be the leader-types in a group. Therefore, these problems need to be carefully considered to ensure positive results in any group performance. Teamwork requires the different individuals in a group to collaborate in sharing ideas and information to attain a similar goal (Buchanan, 1998). In an academic setting, a study by Tarricone and Luca (2002) determined a framework that educators can apply to encourage effective teamwork in their classes. The framework includes the following: (1) commitment to team success; (2) interdependence; (3) interpersonal skills; (4) open communication and positive feedback; (5) appropriate team composition; (6) commitment to team processes; (7) leadership; and (8) accountability.

Measurement of an individual performance is another problem in a group project. Individual accountability is essential to ensure successful group work (Davis, 1999). Previous studies developed a peer assessment method to 
assess the performance of students in a group project (Muhammad et al., 2008; Mahenthiran \& Rouse, 2000). Peers work closely together and have a greater number of truthful behavioral observations (Friedman, 2008; Greguras et. al, 2001). Peer assessment has been widely used in many applications, such as oral presentations, writing, group projects, and tests (Fachikov \& Goldfinch, 2000; Topping, 1998). Massingham et al. (2011) stated that this system collects information from diverse sources, which is known as the 360-degree feedback. This assessment can engage students in active learning (Ballantyne et. al, 2002; Topping, 1998; Healey, 1997). As Clary (1997) mentioned, the two main components of a successful peer review process are (1) feedback from team members based on noticeable behavior and (2) a supportive team environment. Teams with peer assessments perceived higher levels of workload sharing, participation, performance, and team member satisfaction (Friedman et. al, 2008; Davis, 1999). Tarricone and Luca (2002) determined that findings from the first peer assessment session significantly help in identifying any of team members that do not contribute. Therefore, this method can help indicate if a group requires division or if they could continue with the current members. However, the information gathered from a peer review may not be absolutely accurate (Friedman et al., 2008). A good peer review entails the capability and enthusiasm of students to rate their teammates (Friedman et. al, 2008). As Friedman et al. (2008) mentioned, instructors often use peer ratings to ascertain grades without providing feedback to students. Hence, students may have little motivation to deliver meaningful assessments. Similar scores and bias toward group members or individuals are other examples of the issues that Dyrud (2001) highlighted. Lecturer evaluation may help solve this problem, as the participation of more parties in the assessment process can influence the accuracy of individual performance marks (Massingham et al., 2011).

This study describes two types of sources to evaluate individual performance in a group project, namely, (1) peer review and (2) lecturer evaluation. Peer review is a tool that uses members in a group to rate each other based on several characteristics. Lecturer evaluation is another measurement tool that uses two or more lecturers to provide ratings to particular students based on oral presentations and group reports. Both tools are fair regarding grades distribution among active students and passive students. This study also explores the relationship between the two methods in determining individual performance.

\section{Method}

This study was conducted among a total of 66 first year students for two consecutive semesters. The respondents were divided into 13 groups, with each group having five or six members of various races and genders. In the group project, all students were required to be involved to ensure that project goals are achieved. The main objectives of both courses are (1) to ensure that students understand the importance of teamwork and (2) to develop their critical-thinking skills as future engineers.

Regarding the peer review method, each student needs to evaluate the characteristics of his or her group members after the presentation. For this method, the Likert Scale rating of 1 (strongly disagree) to 5 (strongly) was used. The criteria for the peer review are presented in Table 1, and included an assessment of individuals working together as a group. The criteria were developed based on past experiences in the department.

Table 1. Criteria for peer review method

\begin{tabular}{ll}
\hline No. & \multicolumn{1}{c}{ Criteria } \\
\hline P1 & $\begin{array}{l}\text { Ability to negotiate among members and respect other opinions as well as stimulate a discussion to } \\
\text { achieve the desired result }\end{array}$ \\
P2 & $\begin{array}{l}\text { Ability to work in a team to achieve the same objectives (builds a good relationship, interacts, and works } \\
\text { effectively with other members) }\end{array}$ \\
P3 & Ability to respect the opinions, position, and beliefs of others \\
P4 & Ability to contribute to the planning and coordination of the efforts of the group \\
P5 & Ability to perform responsibilities with integrity and trust (does not cheat during the preparation of the \\
& paper) \\
P6 & Ability to improve based on the comments received \\
P7 & Ability to manage time and meet the due date \\
P8 & Ability to show tolerance for cultural diversity
\end{tabular}

For the lecturer assessment, scores were given during the presentation of a team member for the group project and the group report. The criteria for oral evaluation are based on communication skill. Five ratings were used for this assessment: 5 for "excellent," 4 for "good," 3 for "satisfactory," 2 for "not adequate," and 1 for "not 
enough.” Each rating has an explanation per criterion, which the lecturers used to evaluate each student directly when they presented their projects. This assessment has six criteria, as presented in Table 2.

Table 2. Criteria for oral evaluation

\begin{tabular}{ll}
\hline No. & Criteria \\
\hline K1 & posture and interaction points \\
K2 & speaking guide \\
K3 & order \\
K4 & visual aids \\
K5 & knowledge level of the subject \\
K6 & reaction to the question (style) \\
\hline
\end{tabular}

Two main categories were highlighted for the group report: (1) content and (2) overall report. Table 3 presents the criteria for the group report.

Table 3. Criteria for group report

\begin{tabular}{ll}
\hline Content & \\
\hline L1 & Good introduction \\
L2 & Strong problem statement \\
L3 & Relevant references \\
L4 & Acceptable conclusion \\
Overall & \\
L5 & List of content \\
L6 & Structured format (topic and subtopic) \\
L7 & Language structure \\
L8 & Variety of research material \\
L9 & Ability to choose and make decision \\
L10 & Ability to give opinion \\
\hline
\end{tabular}

\section{Results and Discussions}

\subsection{Comparison on Individual Performance Based on Lecturer Evaluation and Peer Review}

Using Microsoft Excel, the performance of students was compared based on the scores for two consecutive semesters. In the current project, the allocations were $50 \%$ for the group report based on lecturer evaluation, $40 \%$ for the presentation based on lecturer evaluation, and $10 \%$ for the peer review based on scores from team members. The percentages correspond to the maximum marks used for the three tools.

Figure 1 presents the performance based on the group report mark. Student no. 6 indicates a significant improvement on the group report mark, whereas Student no. 31 demonstrates a significant decrease from Semester $1(43 \%)$ to Semester $2(37 \%)$. However, this group report does not fully represent individual performance because the task was performed in a group. 


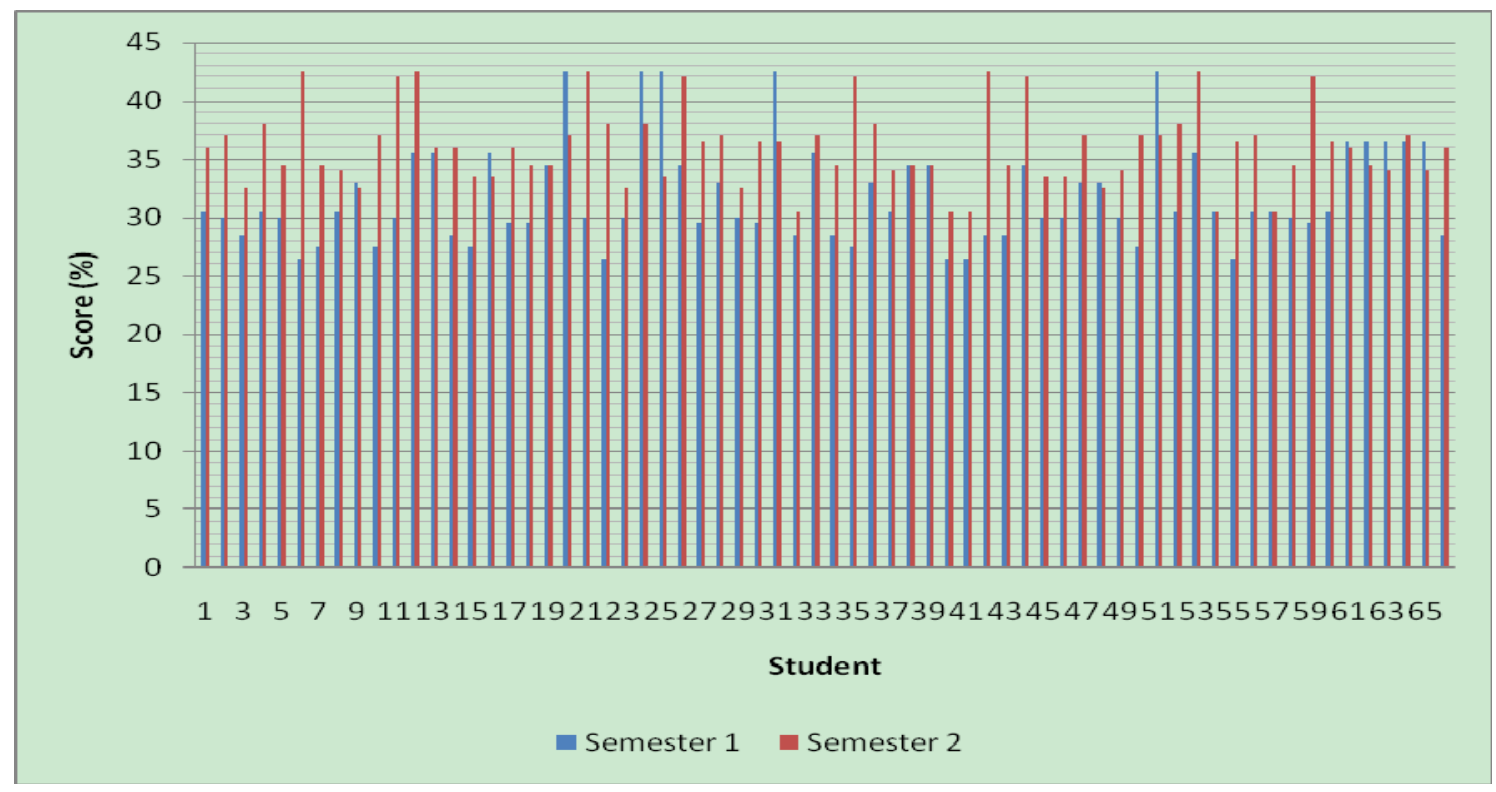

Figure 1. Group report score for semester 1 and semester 2 session 2010/2011

Figure 2 presents the performance based on the presentation mark. In relation to Figure 1, Student no. 62 demonstrates a significant improvement during Semester 2 (39\%), whereas Student no. 48 demonstrates a significant decrease from Semester $1(31 \%)$ to Semester $2(21 \%)$.

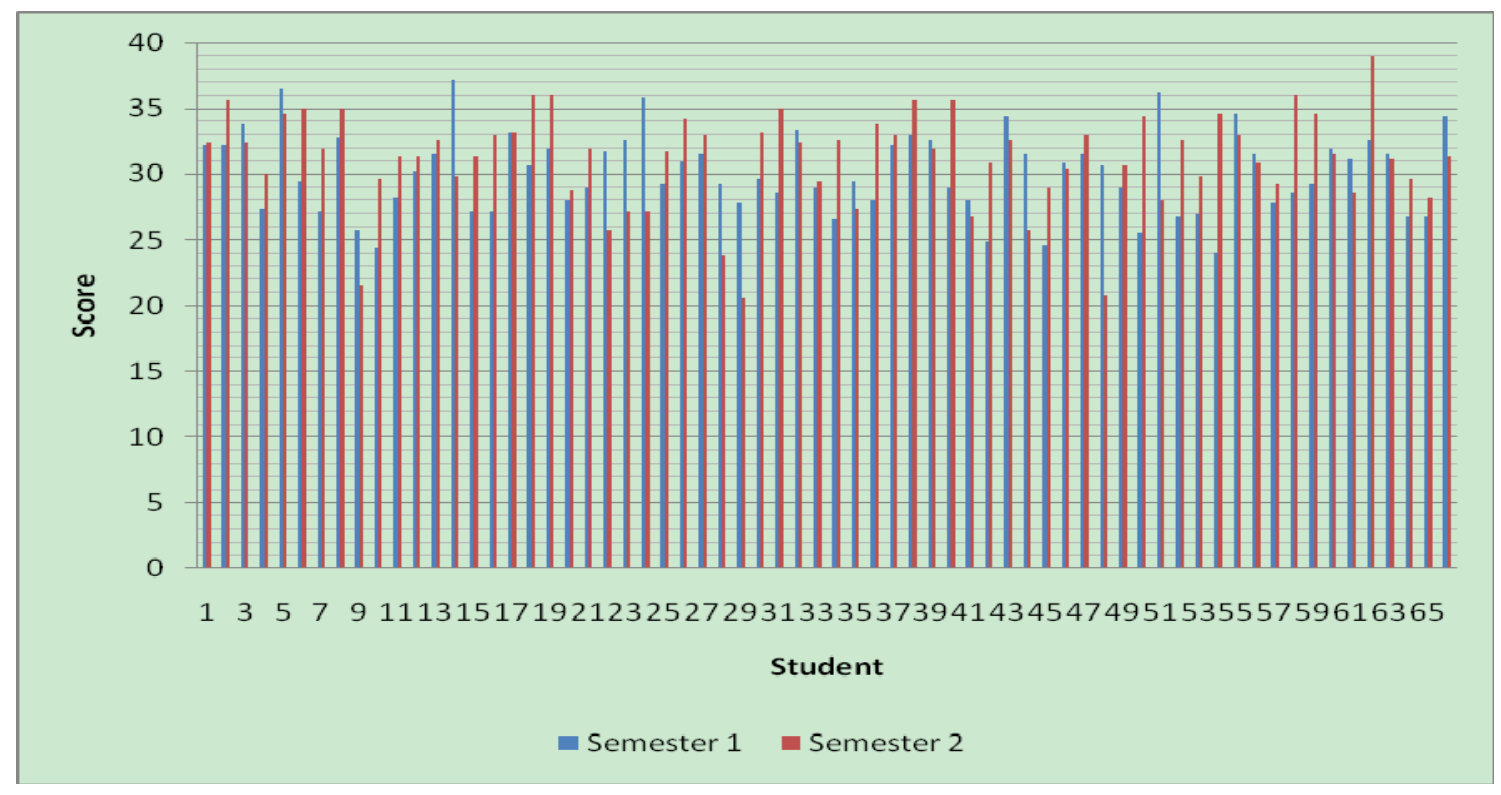

Figure 2. Oral score for semester 1 and semester 2 session 2010/2011

Figure 3 presents the performance based on the peer review mark. Majority of the students demonstrate an improvement on peer review scores from Semester 1 to Semester 2. However, Student no. 62 scored a one-mark drop from Semester 1(10\%) to Semester $2(9 \%)$ in the peer evaluation, and Student no. 48 gained a similar mark for both semesters $(9 \%)$. These results may be due to the different group members in two consecutive semesters. 


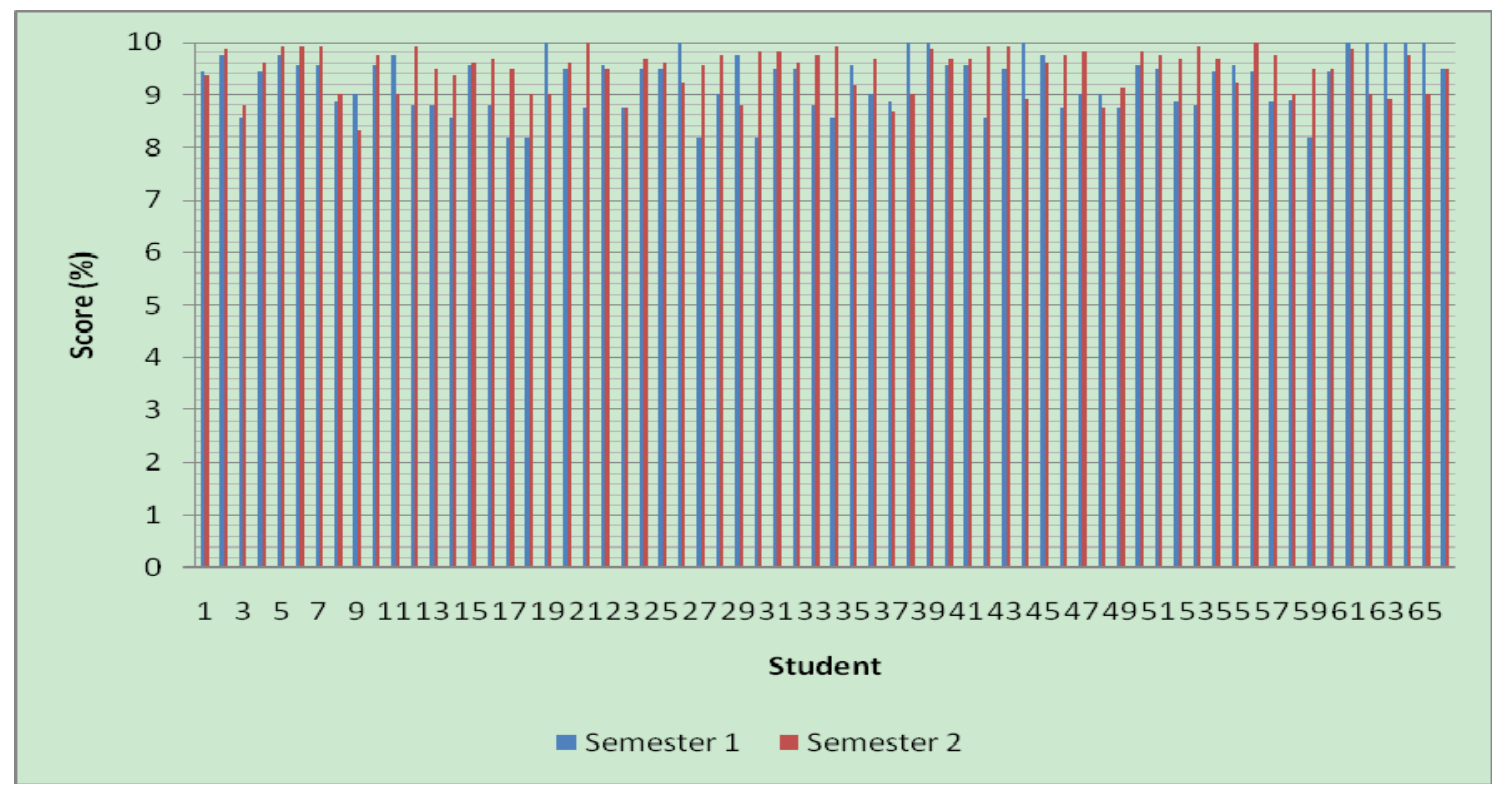

Figure 3. Peer review score for semester 1 and semester 2 session 2010/2011

\subsection{Performance based on the Individual Measurement}

Figures 4 and 5 present the score levels for the students based on the two types of individual assessments (oral evaluation and peer review) for both semesters are almost the same.

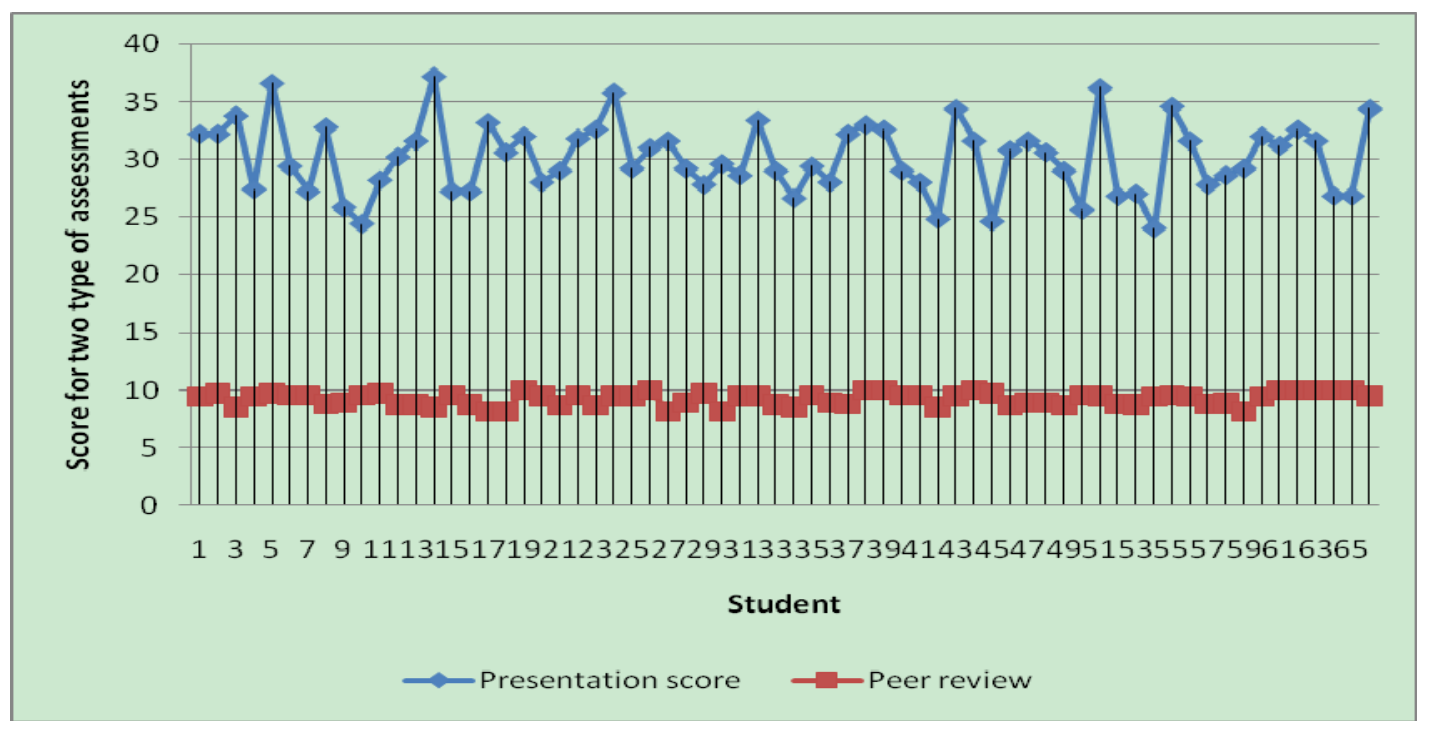

Figure 4. Presentation score and peer assessment score for semester 1 session 2010/2011 


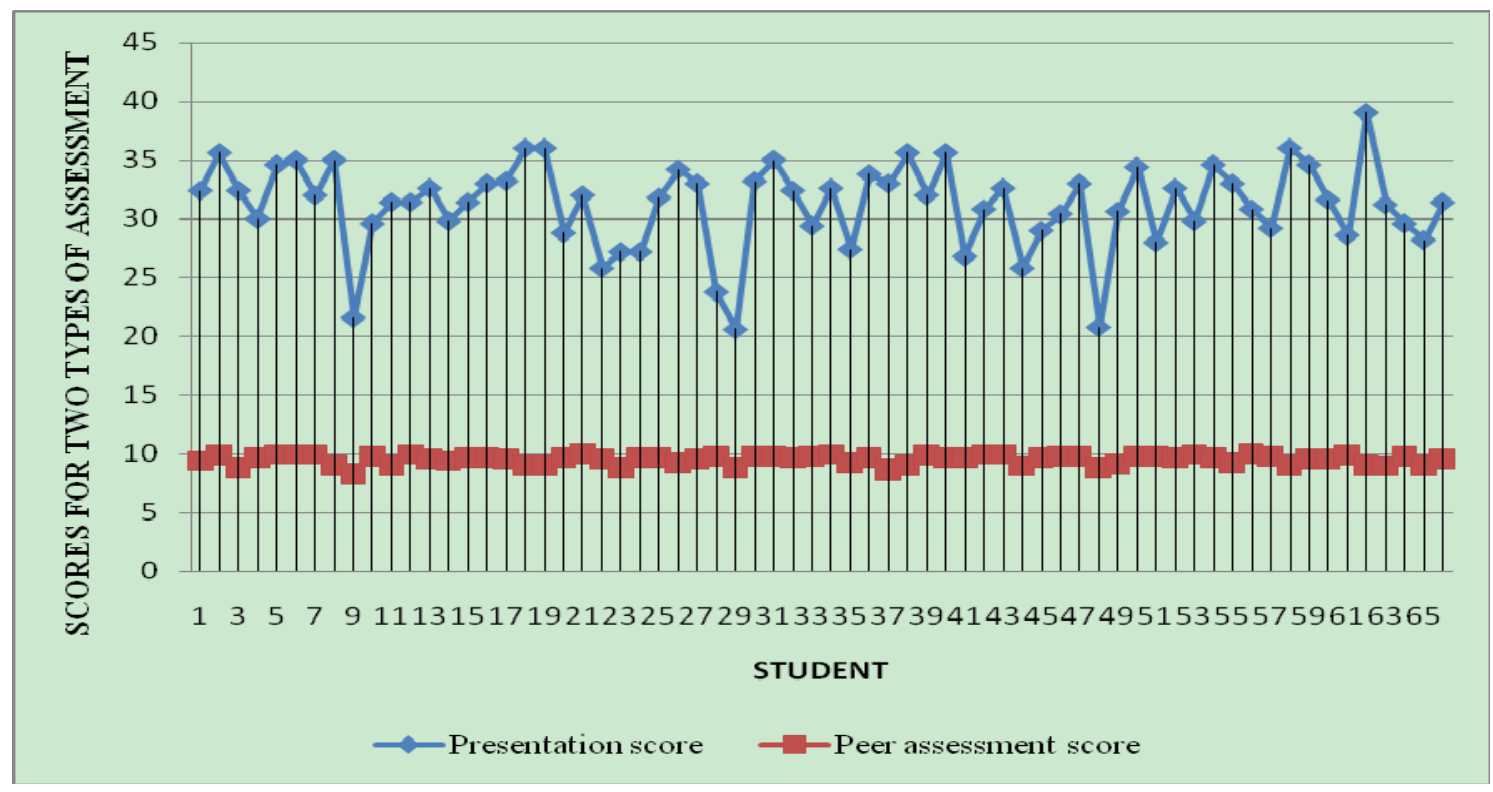

Figure 5. Presentation score and peer assessment score for semester 2 session 2010/2011

With regards to Figures 4 and 5, the peer review and lecturer evaluation methods may help recognize the pattern of individual scores. Based on Figure 5, approximately 40 students obtained marks above $30 \%$ (for lecturer evaluation) and above $9 \%$ (for peer review) for both assessments; whereas less than 5 students obtained marks below $29.9 \%$ (for lecturer evaluation) and below $8.9 \%$ (for peer review). However, these results still do not explain the actual relationship between both assessments in determining student performance. The next section explores the relationship between these two variables.

\subsection{Correlation}

A Statistical SPSS software program was used to study the correlation between peer review and lecturer evaluations for both semesters using four items. This study is an extension of the results from a previous research by Khamis and Sulong (2011), which states that the correlation between peer review and overall presentation score is not significant. However, the present study further explores another evaluation for both semesters.

\subsubsection{Relationship between the Peer Review and the Overall Presentation Score}

The Pearson correlation coefficient between the peer review and the presentation scores for Semester 1 is +0.04 , whereas that for Semester 2 is +0.22 . Although the coefficients are positive, the values are less than +0.30 , indicating an insignificant correlation between the two variables.

\subsubsection{Relationship between the Peer Review and Group Report Marks}

The Pearson correlation coefficient between the peer review and the presentation scores for Semester 1 is +0.238 , whereas that for Semester 2 is +0.257 . Although the coefficients are positive, the values are less than +0.30 , indicating an insignificant correlation between the two variables.

\subsubsection{Relationship between the Lecturer Evaluation (Presentation and Group Report) and Peer Review}

The Pearson correlation coefficient between the peer review and the presentation scores for Semester 1 is +0.2 , whereas that for Semester 2 is +0.32 . Although the coefficients are positive, the values are between 0.2 and 0.32 , indicating a small and large correlation between the two variables, respectively. Thus, peer review may help evaluate student performance from the perspective of a team member.

\section{Conclusion}

Effective group performance depends on organizational, group, and individual factors. The strengths and weaknesses of group members can be determined through the peer review and lecturer evaluations of presentation sessions and group reports. These evaluations also assist in identifying passive students in a group project. In this paper, the relationship between both variables (peer review and lecturer evaluations) was identified. Results indicate that peer review and lecturer evaluations may help evaluate student performance from the perspective of both a team member and lecturer. Peer review is designed to be fair in grading students when working in a group with friends with similar age, whereas lecturer evaluation only views the performance of 
students as a group during oral sessions and in writing skills. However, findings vary due to the different perspectives and opinions of the different evaluators. In general, grading the overall group achievement should be based on the success of the final product and the group self-evaluation of its operations.

\section{Acknowledgements}

The authors thank the Department of Mechanical and Materials Engineering and Centre of Engineering Education at the Universiti Kebangsaan Malaysia, Bangi for supporting this study. This work was supported by the Research University Grants PTS-2012-008 and OUP-2012-126.

\section{References}

Ballantine, J., \& Larres, P. M. (2007). Cooperative learning: a pedagogy to improve students' generic skills? Education + Training, 49, 126-137

Ballantyne, R., Hughes, K., \& Mylonas, A. (2002). Developing procedures for implementing peer assessment in large classes using an action research process. Assessment \& Evaluation in Higher Education, 27(5), 427-441. http://dx.doi.org/10.1080/0260293022000009302

Buchanan, L. B. (1998). The Impact of Big Five Personality Characteristics on Group Cohesion and Creative Task Performance. PhD Thesis.

Canada, R., \& Reddington, C. (2006). How does student participation influence student achievement? New York University, Spring Semester 2006.

Cappelli, P. (1992). College students and the workplace: Assessing performance to improve the fit. Change, 24(6), 54-61. http://dx.doi.org/10.1080/00091383.1992.9937715

Clary, C. R. (1997). Using Peer Review to Build Project Teams: A Case Study. NACTA Journal.

Coopers, \& Lybrand. (1998). Skills development in Higher Education. Report for CVCP/DfEE/HEQE, November. London: Committee of Vice-Chancellors and Principals of the universities of the UK (CVCP).

Davis, B. G. (1999). Cooperative learning: Students working in small groups. Speaking of Teaching: Stanford University Newsletter on Teaching, 10(2).

Dyrud, M. A. (2001). Group Projects and Peer Review. Business Communication Quarterly, 64, 106. http://dx.doi.org/10.1177/108056990106400412

Falchikov, N., \& Goldfinch, J. (2000). Student peer assessment in higher education: A meta-analysis comparing peer and teacher marks. Review of Educational Research, 70(3), 287-322.

Friedman, B. A., Cox, P. L., \& Maher, L. E. (2008). An expentacy theory motivation approach to peer $\begin{array}{llll}\text { assessment. Journal of Management Education, 32(5), 580-612. } & \text {. }\end{array}$ http://dx.doi.org/10.1177/1052562907310641

Greguras, G. J., Robie, C., \& Born, M. P. (2001). Applying the social relations model to self and peer

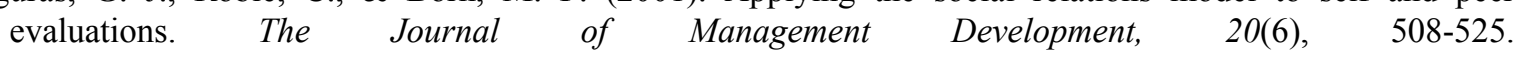
http://dx.doi.org/10.1108/02621710110399792

GSN (Global School Net). (2012). Harnessing the web. Retrieved from http://www.globalschoolnet.org/web/index.htm

Gueldenzoph, L. E., \& May, G. L. (2002). Collaborative peer evaluation: Best practices for group member

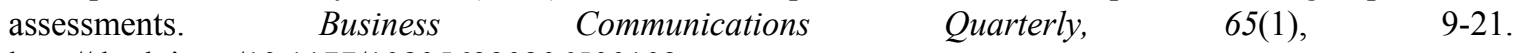
http://dx.doi.org/10.1177/108056990206500102

Healey, M. (1997). Using peer and self assessment for assessing the contribution of indviduals to a group project. Geography Discipline Network.

Hoegl, M., \& Gemuenden, H. G. (2001). Teamwork quality and the success of innovative projetcs: A theoretical concept and empirical evidence. Organization Sceince, 12(4), 435-449. http://dx.doi.org/10.1287/orsc.12.4.435.10635

Ingram, H. (1996). Linking teamwork with performance. Team Performance Management, 2(4), 5-10. http://dx.doi.org/10.1108/13527599610131854

Jackson, S. E., May, K. E., \& Whitney, K. (1995). Understanding the dynamics of diversity in decision-making teams. In Guzzo, R. A., \& Salas, E. (Eds.), Team effectiveness and Decision Making in Organizations (pp. 
204-261). Jossey-Bass, San Francisco, CA.

Keck, S., \& Tushman, M. (1993). Environmental and organizational context and executive team structure. Academy of Management Journal, 36(6), 1314-1344. http://dx.doi.org/10.2307/256813

Khamis, N. K., \& Sulong, A. B. (2011). Pengukuran Tahap Prestasi Pelajar dalam Projek Berkumpulan Melalui Kaedah Penilaian Rakan Sebaya dan Penilaian Pensyarah: Satu Kajian. Kongres Pembelajaran dan Pengajaran UKM. Penang.

Lees, D. (2002). Graduate Employability-Literature Review. LTSN Generic Centre.

Liao, W. C., \& Tsai, C. C. (2001). A study of cockpit crew teamwork behaviors. Team Performance Management, 7(1), 21-27. http://dx.doi.org/10.1108/13527590110389574

Mahenthiran, S., \& Rouse, P. J. (2000). The impact of group selection on student performance and satisfaction. The international Journal of Educational Management, 14, 255-264. http://dx.doi.org/10.1108/09513540010348043

Massingham, P., Nguyen, T. N. Q., \& Massingham, R. (2011). Using 360 degree peer review to validate self-reporting in human capital measurement. Journal of Intellectual Capital, 12(1), 43-74. http://dx.doi.org/10.1108/14691931111097917

MOHE, (2011). Portal Rasmi Kementerian Pengajian Tinggi. Retrieved from http://www.mohe.gov.my/portal/institusi/ipts.html

Muhammad, N., Abd. Wahab, D., Khamis, N. K., Wahid, Z. A., Ghani, J., Md Deros, B., ... Ismail, A. R. (2008). Kajian Pelaksanaan Kaedah Penilaian Rakan Sebaya dalam Projek Berkumpulan. PEKA 2008, Bukit Merah, Perak.

Pfeffer, J. (1983). Organizational demography. Research in Organizational Behavior, 5(3), 299-357.

Strangman, N., \& Hall, T. (2009). Background knowledge. NCAC.

Tarricone, P., \& Luca, J. (2002). Successful teamwork: A case study. HERDSA, 640-646.

Topping, K. (1998). Peer assessment between students in colleges and universities. Review of Educational Resarch, 68(3), 249-276.

Warn, J., \& Tranter, P. (2001) Measuring quality in higher education: a competency approach. Quality in Higher Education, 7(3), 191-199. http://dx.doi.org/10.1080/13538320120098078 